Bu makaleye atıfta bulunmak için/To cite this article:

EREM, N. (2021). Gümrük Birliği Teorisi ve İktisadi Bağlamda Statik ve Dinamik Etkileri. Atatürk Üniversitesi Sosyal Bilimler Enstitüsü Dergisi, 25 (3), 903-920.

\title{
Gümrük Birliği Teorisi ve İktisadi Bağlamda Statik ve Dinamik Etkileri $\left(^{*}\right)$
}

Nurullah EREM (**)

Öz: Küresel entegrasyon sistemi ülke ekonomileri için çeşitli risk ve tehditler oluşturmakla birlikte, bu ekonomiler için önemli firsatları da bünyesinde barındırmaktadır. Bölgesel ve küresel ölçekte yeni ekonomik dengeler kurulmaktadır. Özellikle gelişmekte olan ekonomiler için kırılganlığın arttığı bir ortamda hiç kuşkusuz bütün bu güç dengelerini uluslararası rekabet gücünden bağımsız değerlendirmek mümkün değildir. Bir taraftan GATT ve devamında DTÖ'nün uluslararası ticareti serbestleștirme yönündeki çabaları sonucunda dünya ticaretindeki liberalleșme eğilimleri güçlenirken, diğer taraftan bu serbestleșme düşüncesine ve uygulamalarına tezat olarak görülebilecek istisna kapsamında, 1950’lerden sonra bașta gümrük birlikleri olmak üzere bölgesel ekonomik entegrasyonlar önemli bir ivme kazanmıștır. $\mathrm{Bu}$ bölgesel ekonomik entegrasyonların en önemlilerinden birisi gümrük birlikleridir. $\mathrm{Bu}$ çalışmamızda gümrük birliklerinin oluşumuna genel olarak değinildikten sonra, gümrük birliği teorisi ve iktisadi bağlamda statik ve dinamik etkileri ayrıntıll olarak değerlendirilecektir.

Anahtar Kelimeler: Ekonomik entegrasyonlar, gümrük birliği teorisi, uluslararası ticaret.

\section{Customs Union Theory and Its Static and Dynamic Effects in the Economic Context}

Abstract: As a result of the developments in the global economy, while international trade develops on the one hand, it also faces great risks and uncertainties on the other. New economic balances are established on a regional and global scale. Undoubtedly, it is not possible to evaluate all these power balances independently of international competitiveness, especially in an environment of increased fragility for developing economies. On the one hand, as a result of the efforts of the GATT and the WTO to liberalize international trade, the liberalization tendencies in world trade strengthened, on the other hand, within the scope of the exception that can be seen as a contradiction to this liberalization idea and practices, regional economic integrations, especially the customs unions, gained significant momentum after the 1950s. One of the most important of these regional economic integrations is the customs unions. In this study, after general mention of the formation of customs unions, the theory of customs union and its static and dynamic effects in the economic context will be evaluated in detail.

Keywords: Economic integrations, customs union theory, international trade.

\footnotetext{
* ) Bu çalışma, Prof. Dr. Ali ŞEN danışmanlığında Nurullah Erem tarafından 16.06.2015 tarihinde tamamlanan "Gümrük Birliği Sürecinde Türkiye İmalat Sanayii Rekabet Gücünün AB (15) Ülkeleri ile Karşılaştırmalı Analizi: 1989-2013” başlıklı doktora tezinden türetilmiştir.

**) Dr. Öğretim Üyesi, Samsun Üniversitesi İISBF Uluslararası Ticaret ve İşletmecilik Bölümü (eposta: nurullah.erem@samsun.edu.tr) (D) ORCID ID. https://orcid.org/0000-0002-9892-8696

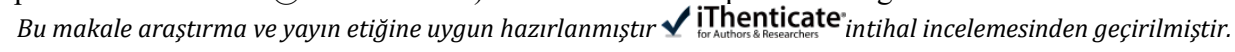


Makale Geliș Tarihi: 30.04.2021

Makale Kabul Tarihi: 23.09.2021

DOI: $10.53487 /$ ataunisosbil.930685

\section{Giriş}

Günümüzde ülkeler bir yandan ekonomik olarak hızlı bir entegrasyon süreciyle yeni ve güçlü bloklaşmalara giderken, diğer taraftan bu entegrasyon ve bloklaşma süreci yıkıcı ve dengeleri bozucu bir rekabet ortamına da zemin hazırlamaktadır. Uluslararası ekonomik entegrasyon hareketleri, konuya ilişkin literatürde gevșek örgütlenme modellerinden daha sıkı örgütlenme modellerine doğru genel olarak beş başlık altında incelenmektedir: Tercihli ticaret anlaşmaları ve alanları, serbest ticaret bölgeleri, gümrük birlikleri, ortak pazar, ekonomik birlik ve siyasal bütünleşmeler.

Bazı ülkeler daha bağımsız ekonomik politikalar yürütmekle birlikte, uluslararası ticaretin serbestleşmesinden kaynaklanan avantajlardan daha fazla istifade edebilmek için daha gevşek ve entegrasyon düzeyi diğerlerine göre daha az olan tercihli ticaret anlaşmaları ile serbest ticaret anlaşmalarına yönelirken, bazı ülkeler de daha sıkı ve entegrasyon düzeyi diğerlerine göre fazla olan gümrük birlikleri, ortak pazar ve ekonomik birlik ve siyasal bütünleşme şeklinde olan entegrasyon çeşitlerine yönelmektedirler. Bu bloklaşmaların en önemlilerinden birisi de gümrük birlikleridir. Gümrük birliği, birliğe üye olan ülkelerin mallarının ortak bir gümrük alanı içerisinde, her türlü tarife ve eşdeğer vergiden muaf olarak serbestçe dolaşabilmeleri ve birliğe üye ülkelerin, üçüncü ülkelerden gelen mallara yönelik olarak aynı tarife oranları ve aynı ticaret politikalarını, diğer bir ifadeyle ortak gümrük tarifesi uygulamalarını ifade etmektedir.

Ortak gümrük tarifesi, bir gümrük birliğinin en kritik özelliklerinden birini oluşturduğundan, yalnızca ortak bir gümrük politikasını değil, ortak bir dış ticaret politikasını da içermektedir. Bir gümrük birliğinde malların serbest dolaşımı konusunda istisnalar bulunmakla birlikte, genel olarak serbest dolaşım malların menşeinden bağımsız olarak uygulanır, dolayısıyla malların serbest dolaşımda bulunup bulunmadığı konusu gümrük birliğinin en önemli kriterlerinden birisi haline gelmektedir. Bu çalışmada gümrük birliği adlı başlık altında, gümrük birliği düşüncesinin oluşumu ile ekonomik entegrasyon çeşidi olarak gümrük birlikleri konusu ele alınmaktadır. Gümrük birliği teorisi adlı başlık altında, gümrük birliği teorisinin oluşum süreci incelenmektedir. Gümrük birliğinin ekonomik etkileri başlığı altında ise, gümrük birliğinin statik etkileri ile dinamik etkileri araştırılmaktadır.

\section{Gümrük Birliği}

2. Dünya Savaşından sonra, 25 yıl arayla iki büyük ve yıkıcı savaş yaşayan Dünya'nın önde gelen ve savaşlardan etkilenen ülkeleri, bir daha böylesine insanlık tarihi için felaketlerle sonuçlanacak savaşları yaşamamak için başta Birleşmiş Milletler olmak üzere çok sayıda uluslararası kurum ve kuruluşun kurulmasına öncülük etmişlerdir. Bu kurumsal yapıların en önemlilerden biri de Gümrük Tarifeleri ve Ticaret Genel Anlaşması'dır (GATT). GATT için her ne kadar kurumsal yapı ifadesi kullanılsa da, aslında uluslararası ticareti, ülkelerin hakları ve sorumlulukları açısından düzenleyen çok taraflı bir anlaşmadır. 
23 ülke tarafından 1947 yılında kurulan GATT, 1 Ocak 1948 tarihinde yürürlüğe girmiştir. GATT'ın kuruluş amacı, ticarette ayrımcı uygulamalara son vermek, uluslararası ticaretin önündeki engelleri kaldırmak ve gümrük tarifelerini azaltmak olarak belirlenmiștir. GATT varlığını 1994 yılına kadar devam ettirmiş, 1 Ocak 1995 tarihinden itibaren yerini Dünya Ticaret Örgütü'ne (WTO-DTÖ) bırakmıștır. Her iki oluşumun gayesi de uluslararası ticaretin önündeki engelleri kaldırarak, olabildiğince ticareti serbestleştirmektir.

Dolayısıyla 1947 yılından sonra oluşturulan uluslararası ticaret sisteminin temelini ayrımcı olmama esası oluşturmaktadır. Bu esas GATT ve DTÖ kurallarının temelini oluşturmaktadır. Ayrımcı olmama kuralına göre, DTÖ üyesi bir ülke herhangi bir ülkeye tanıdığı avantajlı ticaret tarifesini herhangi bir şarta bağlı olmadan tüm üye ülkelere de tanımak zorundadır. Bununla birlikte GATT anlaşması ve bu anlaşmayı devralan DTÖ, üye ülkelerin gümrük birlikleri oluşturmalarına ve serbest ticaret anlaşmaları yapmalarına ve böylece diğer DTÖ üyesi ülkelere klyasla tercihli uygulamada bulunmalarına imkân tanımaktadır. Bu imkân GATT ve DTÖ sisteminin temelini olușturan ayrımcı olmama kuralı için en önemli istisnalardan birini oluşturmaktadır (Doğan ve Uzun, 2014: 327).

Bir başka ifadeyle DTÖ hem ayrımcı olmama kuralına istisna oluşturan gümrük birliği vb. bölgesel ticaret anlaşmalarına imkân sağlamakta, hem de bu kurallara ilişkin uyulması gerekli olan genel çerçeveyi oluşturmaktadır. Dünya Ticaret Örgütü'nün bölgesel ticaret anlaşmalarına ilişkin düzenlemeleri bir taraftan üçüncü ülkelerin haklarını korumayı ve güvence altına almayı amaçlarken, diğer taraftan bu tür düzenlemelerin çok taraflı sistem ile uyumlu olmasını da amaçlamaktadır.

Bölgesel ticaret anlaşmaları çok taraflı ticaret sisteminde getirilen bir istisna niteliğinde olup GATT anlaşmasının 24'üncü maddesi ile düzenlenmektedir. Konuya bu açıdan bakıldığında gümrük birlikleri oluşumunun hukuki olarak önemli ölçüde bu istisnaya dayandığı görülecektir. Buna ilave olarak GATT'ın ticaret ve kalkınmaya ilișkin 4. Bölümü ve 1979 yılındaki Tokyo Turu ile yürürlüğe giren "Yetkilendirme Hükmü" (Enabling elause) kararı ile gelișen ülkelerin bölgesel ticaret anlaşmalarına katılmalarını kolaylaştıran yeni hükümler getirilmiştir. Ayrıca yine GATT anlaşmasının aykırılık kararlarını düzenleyen 25'inci maddesi bölgesel ticaret anlaşmalarının GATT hukuku açısından yasal bir çerçeveye kavușturulmasına yardımcı olmaktadır (Gürlesel ve Alkin, 2010: 25).

Gümrük birlikleri, birliğe taraf olan ülkelere ait malların ortak bir gümrük alanı içerisinde, her türlü tarife ve eşdeğer vergiden muaf olarak serbestçe dolaşabilmeleri ve birliğe üye ülkelerin, üçüncü ülkelerden gelen mallara yönelik olarak aynı tarife oranları ve aynı ticaret politikalarını, diğer bir ifadeyle ortak gümrük tarifesi uygulamalarını ifade etmektedir. Ortak gümrük tarifesi hem ortak bir gümrük politikasını hem de ortak bir dış ticaret politikasını kapsar. Bir gümrük birliğinde malların serbest dolaşımda olması, malların menșeinden bağımsız olarak uygulanır. Dolayısıyla üye ülkelerin iç sınırlarında gümrük kontrolleri kaldırılır (Moussis, 2004: 85).

Gümrük birliği kavramının en önemli dayanağı GATT'ın 24'üncü maddesidir. Uluslararası hukuka göre gümrük birliklerini tanımlayan ve hukuki altyapılarını oluşturan 3 temel metin bulunmaktadır. Bunlardan ilki; GATT'ın 24'üncü maddesinin 8'inci paragrafında yapılan tanımlama, ikincisi Roma Antlaşması'nın 9'uncu maddesi ve üçüncü olarak La Haye Uluslararası Adalet Divanı'nın konuya ilişkin bir kararıdır. 
Roma Antlaşması'nın 9'uncu maddesi, gümrük birliğinin uygulanmasından söz etmektedir. Uluslararası Adalet Divanı'nın kararına göre gümrük birliği; birliğe üye olmayan ülkelere karşı ortak bir gümrük vergisinin uygulandığı, birlik içindeki üye ülkeler arasında gerçekleşen mal alım-satımlarında uygulanan gümrük vergisinin tamamen ortadan kaldırıldığı, üçüncü ülkelerden ithal edilen mallardan alınan vergilerin birliğe üye olan ülkeler arasında paylaşıldığı bir birliktir. GATT ve Divan Kararı'nda bulunan tanımlamadaki ortak unsurlar, birlik üyesi ülkeler arasında mal ticaretine uygulanan bütün gümrük vergileri ile eş etkili vergilerin kaldırılması ve üçüncü ülkelere karşı ortak bir gümrük tarifesinin uygulamaya konulmasıdır (Erçakar, 2005: 164).

Gümrük birliklerinde, birliğe üye ülkelerin serbest ve bağımsız bir dış ticaret politikası uygulamasına sınırlandırma getirilmiştir. Bu sınırlandırma göz önünde bulundurulduğunda gümrük birlikleri serbest ticaret bölgelerine göre daha ileri bir ekonomik entegrasyon düzeyini ifade ederler (Dura ve Atik, 2007: 7). Gümrük birliğinde, üye ülkeler arasındaki tarife ve kota sınırlamaları kaldırılarak yalnızca mal ve hizmetler için ortak bir serbest dolaşım mekanizması oluşturulmaktadır. $\mathrm{Bu}$ açıdan değerlendirildiğinde, daha ileri bir entegrasyonu hedefleyen üretim faktörlerinin ülkeler arasındaki hareketliliği ile genel olarak ekonomi ve dış ticaret politikalarının birleștirilmesi, ekonomik birleşmelerin bu aşamasında tam olarak söz konusu değildir. J. Viner'e göre, birkaç ülkenin bir araya gelerek bir gümrük birliği oluşturabilmeleri için, yukarıda belirtilenlere ek olarak, gümrük gelirlerinin tek bir elde toplanması ve önceden belirlenen kriterlere göre paylaşılması da gerekmektedir (Karluk, 1998b: 424).

Gümrük birliğinde üyeler, üçüncü ülkelere karşı uygulayacakları gümrük tarifesini belirleme kararını, olușturdukları ortak karar organına devretmektedirler. Birliğin en önemli kararı olan ortak gümrük tarifesinin nasıl belirleneceği, birliğe üye olan ülkelerin serbest ticareti savunan yaklaşımları ile korumacı yaklaşımlarına göre değişecektir (Yıldız, 1999: 3). Burada serbest ticaret yaklaşımı ağır bastığında gümrük tarifeleri daha düşük belirlenir, korumacı yaklaşım kabul gördüğünde ise gümrük tarifeleri daha yüksek belirlenir.

Gümrük birliklerini ve gümrük birliklerinin ekonomiler üzerindeki etkilerini ayrıntılı ve sistematik olarak ilk inceleyen J. Viner, gümrük birliğinin uygulanabilmesini üç koşulun sağlanması şartına bağlamıştır (Bakkalcı, 2002: 40). Bunlar:

1. Üye ülkeler arasındaki gümrük tarifeleri ve miktar kısıtlamaları kaldırılmalıdır.

2. Birliğe üye ülkeler arasında üçüncü ülkelere karşı uygulanmak üzere ortak gümrük tarifeleri tespit edilmelidir.

3. Gümrüklerden elde edilecek vergi gelirlerinin birliğe üye ülkeler arasında hangi oranda dağıtılacağı belirlenmelidir.

Günümüzde en önemli ve bilinen örnek 1957 yılında Roma Antlaşmasıyla kurulan Avrupa Ekonomik Topluluğu'nun gerçekleștirdiği gümrük birliği projesi olmakla birlikte, tarihte oluşturulmuş başarılı gümrük birliği modelleri de bulunmaktadır. 1789 tarihli Amerika Birleşik Devletleri (ABD) Anayasası, 13 eyalet için ortak gümrük tarifesi öngörerek bir gümrük birliği oluşturmuștur. 1834 yılında siyasi birliğini oluşturamamış küçük Alman devletleri arasında kurulan ve "Zollverein" olarak adlandırılan Alman Gümrük Birliği, 1870'lerde Bismarck tarafından Almanya'nın siyasal birliğinin oluşturulmasına da katkı 
sağlamıștır. Diğer bir örnek, Belçika, Hollanda ve Lüksemburg tarafından 1932'de kurulan "Benelüks" birliğidir. Daha sonra Benelüks üyeleri, Avrupa Ekonomik Topluluğu'nun (AET) kurulmasıyla birlikte 1958 yılında bu topluluğa dâhil olmușlardır (Karluk, 1998b: 424-425; Ertürk, 2006: 57; Kılıç, 2005: 12).

\section{Gümrük Birliği Teorisi}

Gümrük birliği teorisi, gümrük birliğinin birliğe üye ülkeler üzerinde önemli ekonomik yararları olacağını öngörür. Teorik gerçekler kadar ampirik çalışmalar sonucunda elde edilen veriler de gümrük birliği teorisinin anlaşılmasında (teorinin doğrulanması ya da doğrulanmamasında) önemli bir etkendir (Yıldırım ve Dura, 2007: 142). Gümrük birliği teorisi, birliğin oluşumu ile ortaya çıan kazanç ve kayıplara etki eden kaynak dağılımı, ölçek ekonomileri, ihtisaslaşma ve ticaret hadlerini incelerken, birliğin sağladığı faktör verimliliği, ekonomik büyüme ve gelir dağılımını çok fazla göz önünde bulundurmaz (Karluk, 1998a: 213).

Gümrük birliği teorisine göre, koruma duvarlarının kaldırılması sonucunda, birliğe üye ülke ekonomilerinde kısa dönemde statik etkiler meydana gelirken, uzun dönemde ise dinamik etkiler meydana gelir. Kısa dönemde gümrük birliğinin ülkeler arası ticaret hacmini artıracağı beklenirken, uzun dönemde rekabet artışı ile yeniden yapılanma etkilerinden bahsedilebilir. Birliğin gerçekleşmesiyle birlikte ilk anda kısa dönemli etki ortaya çıkmakta ve hesaplanması daha kolay olmakta iken, dışsal koşullar değişebildiği için dinamik analizler gerektiren uzun dönemli etkileri tam olarak hesaplamak daha zor olmaktadır (Kızıltan, Ersungur ve Polat, 2008: 84).

Gümrük birliği teorisinin oluşum sürecinde J. Viner'in 1950'lerde ortaya koyduğu eserler ve çalışmalar konuya ilişkin literatürde neredeyse milat olarak kabul edilmiştir. 0 kadar ki, konuyla ilgili araştırma yapanların büyük bölümü teoriyi, Viner öncesi ve Viner sonrası gümrük birliği teorisine katkılar şeklinde iki döneme ayırarak incelemişlerdir.

Gümrük birliği teorisiyle ilgili ilk kapsamlı ve ciddi çalışma, 1950 yılında Viner tarafından yazılan "Gümrük Birliği Sorunu" (The Customs Union Issue) adlı eserdir. Bu çalışmayı, J.E. Mead'in 1955 yılında yayımlanan "Gümrük Birlikleri Teorisi” (The Theory of Customs Union) adlı eseri takip etmiştir. Her iki çalışma da bu alanda başvurulan iki temel çalışma olarak kabul edilmiştir (Kılıç, 2005: 21). Daha sonra Marcus Fleming, C.A. Cooper, H.G. Johnson, R.G. Lipsey, B.F. Massel ve Kelvin Lancester'in katkıları ile teori bugünkü düzeyine ulaşmıştır (Karluk, 1998a: 212).

1950'lerden itibaren gümrük birliği teorisi yoğun bir şekilde tartışılmış, teorik irdelemenin yanı sıra kurumsal olarak da araştırılarak AET özelinde 1960'lardan itibaren teori genişletilmiş, rafine edilmiş ve yeniden yorumlanmıştır (Ertürk, 2006: 61). Teoriye göre, mal ve faktör piyasalarında tam rekabet şartlarının olduğu, üretim faktörlerinin ülke içinde akışkan, ülkeler arasında ise yeterince akışkan olmadığı varsayılmaktadır. Teknolojik gelişmeyi dışsal bir faktör olarak değerlendirirken, ulaştırma giderlerini sıfır olarak kabul eder. Fiyatların üretimdeki fırsat maliyetlerini tam olarak yansıttığını ileri sürer (Karluk, 1998a: 213). Şimdi gümrük birliği teorisi, Viner öncesi yapılan katkılar, Viner tarafından yapılan katkılar ile Viner sonrası yapılan katkılar olarak üç başlık altında incelenecektir.

Genel olarak ekonomik entegrasyon teorisine, özelde ise gümrük birliği teorisine Viner öncesi yapılan katkılar A. Smith, Taussing, Torrens ve Samuelson'a aittir. A. Smith 1776 
yılında yazdığı "Ulusların Zenginliği" adlı eserinde, gümrük birliğinin faydalarından bahseder. Smith, iki ülke arasında yapılan ticarette gümrük vergileri kaldırılarak diğer ülkelere karşı ortak gümrük tarifesi uygulanırsa, her iki ülkedeki üretici ve satıcıların dolayısıyla tüketicilerin bundan fayda sağlayacaklarını belirtir (Dura ve Atik, 2007: 10).

Viner öncesi teoriye katkı sağlayan önemli iktisatçılardan biri olan Taussing, karşılıklı olarak yapılacak tarife indirimlerinin fayda ve maliyetlerinin ülkelerin ticaretten aldıkları paylarına bağlı olduğunu ileri sürmüştür. Taussing bu durumu, 1876'da Hawai şekerine ABD tarafından verilen preferansların Amerika şeker fiyatlarını çok az etkilediği örneğini vererek açlklamıştır (Ertürk, 2006: 62). Lipsey'e göre Viner'den önce, uluslararası ticarette serbestliğin refahı maksimum yapacağı ve gümrük birliğinin serbest ticaret yolunda önemli bir adım olması dolayısıyla refahı maksimum düzeye çıkarmasa bile artıracağı ifade edilmektedir (Ay, 2005: 21).

Torrens ise, karşılıklı tarife görüşmelerinin çok taraflı tarife görüşmelerine tercih edilmesi gerektiğini savunur. Çok taraflı tarife görüşmelerinin ticaret hadleri üzerinde olumsuz bir etki yaptığını öne sürer (Dura ve Atik, 2007: 10). Torrens, serbest ticaret fikrini benimsememekle birlikte, serbest ticaretin nihai hedef olduğunu ve politik bir bağımlılık yaratacağını, bağımsız ülkelerin optimum tarife uygulayarak ticaretten yarar sağlayacağını, ancak bunun da misilleme olmaması halinde mümkün olduğunu ifade eder (Ertürk, 2006: 63). Ünlü iktisatçılardan Samuelson'a göre, serbest ticaret bütün taraflar için faydalı olan bir iş bölümünü mümkün kılmakta, bütün ülkelerin potansiyel reel milli gelirini önemli ölçüde artırmakta ve bütün dünyada daha yüksek hayat standartlarına imkân sağlamaktadır (Kılıç, 2005: 22).

Hiç kuşkusuz gümrük birliği teorisine en önemli katkı Viner tarafından yapılmıștır. Viner, ticaret yaratıcı (trade creation) etki ve ticaret saptırıcı (trade diversion) etki kavramlarını geliştirmiş, bu kavramlar yardımıyla gümrük birliklerinin dünya refahı üzerindeki etkilerini açıklamıştır. Viner'in teori ile ilgili analizleri gümrük birliklerinin daha çok üretim etkileri üzerine yapılmıștır (Dura ve Atik, 2007: 11). Viner, "The Customs Union Issue" adlı eserinde, "ticaret yaratıcı" ve "ticaret saptırıcı" etkilerden söz ederek gümrük birliği teorisini açıklamaktadır. Ticaret yaratıcı etkide, birliğe katılan bir ülkenin yüksek koruma ile ürettiği bir malı, birlik sonrasında kendisine göre daha ucuz üreten diğer üye ülkelerden ithal etmesi söz konusu olacaktır (Karluk, 1998b: 418). Başka bir ifade ile, ithalat fiyatı arz fiyatından daha düşük olduğundan ülke içi arz kaynağının yerini, birliğe üye diğer bir ülke arz kaynağının almasıdır (Ertürk, 2006: 69).

Ticaret saptırıcı etkide ise, birliğin kurulmasından önce, üye olmayan ancak malı en ucuza üreten ülkeden yapılan ithalatın, birlik sonrasında üye ülkelerden yapılması söz konusudur. Bu durumda, ucuza üretim yapan birlik üyesi olmayan ülkenin yerini, daha pahalı üretim yapan üye ülke almaktadır (Karluk, 1998b: 418). Ticaret yaratıcı etkide, birliğe üye iki ülke arasında üretim yerlerinde değişme meydana gelirken, ticaret saptırıcı etkide düşük maliyetli üçüncü ülkeden, gümrük birliğine üye olan yüksek maliyetli ülkeye ticaretin kayması söz konusu olmaktadır. Viner, gümrük birliklerinin refah artışı sağlayıp sağlamadığını, ticaret yaratıcı ve ticaret saptırıcı etkilerin nispi üstünlüklerine bağlamıştır (Ay, 2005: 21). 
Viner, çalışmasında gümrük birliklerinin tüketim etkisi üzerinde durmamış, teorisini daha çok üretim etkisi üzerine inşa etmiştir. Bu nedenle, malların talep esnekliklerini sıfır, arz esnekliklerini ise sonsuz kabul ederek tam uzmanlaşma varsayımı altında teorisini açıklamaya çalışmıştır (Ertürk, 2006: 70-71).

Viner'in çalışması gümrük birliği teorisine yeni yaklaşımlar kazandırmanın yanı sıra, bu alandaki çalışma ve gayretleri de artırmıștır. Viner'in çalışmasını J. Meade'nin çalışmaları takip etmiştir. Meade, temel kısmi denge yaklaşımı ve kardinalist refah varsayımlarını, kayıp ve kazançları karșılaștırırken kullanmıștır. Meade'nin teoriye yaptı̆̆ en önemli katkı, mallar arası ikame varsayımını analize dâhil etmesi ve sabit maliyetler varsayımını esnetmiş olmasıdır. Meade, ayrıca tüketimi de analize katarak teoriye hatırı sayılır bir katkıda bulunmuștur (Ertürk, 2006: 63). Ayrıca Meade, gümrük birliği kurulduğunda, bazı ithal mallar üzerindeki vergiler kaldırıldığında, üye ülkelerdeki yurtiçi piyasalarda göreceli fiyatların değișeceğini, üretim yapısının sabit kaldığı varsayımında göreceli fiyat değişikliği sonucu malların birbirleri ile ikame edilebilme durumlarının söz konusu olacağını belirtmiştir (Ay, 2005: 22).

Meade tarafından geliștirilen gümrük birliği teorisi R.G. Lipsey ve Kelvin Lancaster tarafından genelleştirilmiştir (Seyidoğlu, 1999: 216-217). Viner çalışmasında gümrük birliğinin tüm dünya refahına katkıda bulunacağını ileri sürmüştür. Ancak, gümrük birliğine üye olmayan ülkelerden yapılan ticaretin ortak gümrük tarifesi ve benzeri yöntemlerle engellenmesi, dünya refahına olumsuz etkide bulunur. Bu nedenle, gümrük birlikleri dünya refahı bakımından bir yönüyle faydalı etkiler doğururken, diğer taraftan zararlı etkilere de neden olabilmektedir (Dura ve Atik, 2007: 11).

Lipsey ve Lancaster gümrük birliği teorisi bağlamında "ikinci en iyi teori"yi geliştirmişlerdir. Tam rekabet koşullarında serbest ticaret, dünya refahını artırması bakımından en iyi politika olarak kabul edilir. Bu politika tercihine "birinci en iyi" de denebilir. Ancak gerçek hayatta ülkeler arasında tam rekabet ve serbest ticaretin mutlak anlamda varlığından söz edilemez. İkinci en iyi teori de bu gerçeklikten yola çıkılarak izah edilmeye çalıșılmıștır (Seyidoğlu, 1999: 215-216). Bu teoriye göre, Pareto optimumu varlığını önleyen çok sayıda engel vardır. Gümrük birlikleri, bu engellerden en azından birisini kaldırmak için kurulduğundan refah düzeyini artırabilir. Bu durum Pareto optimumunu sağlayamamasına karşın, bir Pareto iyileştirmesi olarak görülebilir (Ay, 2005: 24).

Viner'in gümrük birliği teorisini sistematize ederken kullandığı kısmi denge analizi, 1960'lı yılların ortasına kadar tartışma ve eleştirilerin merkezini oluşturmuş, ancak J. Vanek ile meslektaşı M. Kemp ticaret hadleri etkisini de analize dahil ederek genel denge yaklaşımı ile gümrük birliği teorisini daha sistemli ve bütüncül bir yapıya kavuşturmuşlardır (Ertürk, 2006: 64). Vanek'e göre, artan maliyet durumu varsa, gümrük birliğinin ticaret hadlerine etkisi, üçüncü ülke ile yapılan ticaretin miktarına göre değişir. Ticaret hadlerinin belirlenmesinde, ülkenin büyüklüğü kadar, teklif eğrisinin șekli de önemlidir. Teklif eğrisinin esnekliği, daha büyük bir ekonomi ve dıș ticaret ortamıyla karşılașıldığında artacaktır. Teklif eğrisinin esnekliğinin yükselmesi veya sonsuza yakın olması da, ticaret hadlerindeki değişmenin lehine dönmesi beklentisini doğuracaktır (Ay, 2005: 24). 


\section{Gümrük Birliğinin Ekonomik Etkileri}

Gümrük birliğinin ekonomik etkilerini statik ve dinamik etkiler olarak iki başlık altında incelemek mümkündür.

\section{A. Gümrük Birliğinin Statik Etkileri}

Gümrük birliğinin statik etkileri, teknoloji düzeyi ile makro ekonomik yapıda herhangi bir değișikliğin olmadığı varsayımında, üretim faktörlerinin (kaynakların) yeniden dağıtılması sonucunda ortaya çıkacak etkileri ölçmeye yardımcı olan analiz yöntemidir. Ekonomik yapı ve teknoloji uzun süre aynı kalamayacağı için statik etkiler, kısa süreli, anlık ve bir defaya mahsus etkileri açıklamada kullanılır (Dura ve Atik, 2007: 12). Geleneksel dıș ticaret analizlerinde daha çok statik etkiler üzerinde durulmuştur (Seyidoğlu, 1999: 207). Bunun nedeni statik etkilerin daha kolay ve basitleștirici analizlere dayalı olmasıdır.

Gümrük birliğinin statik etkileri, ticaret yaratıcı etkiler ile ticaret saptırıcı etkilerin analiz edilmesi ile anlaşılabilir. Gümrük birliğinden kaynaklanan statik kazanımları belirlerken, bir malı yurt içinde üretmek yerine, o malın daha ucuza ithal edilmesi için vazgeçilen kaynaklar ile bu ithalatı gerçekleștirmek için yapılması gereken ihracattan elde edilen kazanımların kıyaslanması gerekmektedir. Diğer bir ifade ile statik etki veya kazanımlar, ithal edilen malların yurt içinde üretilmemesinden dolayı tasarruf edilen mal miktarının maliyeti ile ithal ikamesi nedeniyle yurt içinde üretimi yapılan mal miktarı maliyetinin karşılaştırılmasıyla ölçülür (Ay, 2005: 29). Bu kısımda gümrük birliğinin statik etkileri, üretim etkileri, tüketim etkileri ve diș ticaret etkileri olarak incelenmektedir.

Gümrük birliklerinin üretim üzerindeki etkileri analiz edilirken, daha önce değinilen ticaret yaratma etkisi (olumlu üretim etkisi) ve ticaret saptırma etkisi (olumsuz ticaret etkisi) kavramlarından yararlanılacaktır. Genel olarak gümrük birliklerinin üretim üzerindeki etkileri, belirli mallara yönelen tüketici talebinin yurtiçi üreticiler ve üçüncü ülkelerden birlik üyesi ülkelere kayması sonucu meydana gelmektedir (Karluk, 1998a: 213).

Viner, ticaret yaratma etkisini, daha yüksek maliyetli olan yerli üretimin birliğe üye diğer ülkeden gelen daha düşük maliyetli ithalatla ikamesi olarak, ticaret saptırma etkisini ise, başlangıçta gümrük birliği dışından gelen ucuz ithalatın, kaynağı gümrük birliği olan pahalı ithalatla ikamesi olarak tanımlamıștır. Viner, ticaret yaratma etkisini refah arttırıcı, ticaret saptırma etkisini ise refah azaltıcı olarak görmüștür (Aynagöz, 2002: 26). Gümrük birliği sonucunda ticaret yaratma etkisinin büyüklügü, birliğe üye olan ülkelerin büyüme ve dolayısıyla refah artışının da yüksek olacağını ifade eder (Gökdemir ve Karaman, 2008: 280). Ancak refah üzerindeki net değişikliğin tespit edilebilmesi için ticareti saptırma etkisinin de hesaba katılması gerekir. Çünkü ticareti saptırma etkisi refahı olumsuz yönde etkiler (Seyidoğlu, 1999: 208).

Birliğin kurulmasıyla birlikte dış ticaret engelleri ortadan kalkınca her mal, birlik içinde o malı en düşük maliyetle üreten ülkeden ithal edilmeye başlanır. Bunun sonucunda daha önce gümrük tarifeleriyle korunan, maliyeti yüksek yerli üretimin yerini, verimliliği yüksek olan düşük maliyetli birlik üyesi diğer ülke alacaktır. Bu durum birlik içinde üretim faktörlerinin yeniden düzenlenmesine ve diș ticaret hacminin artmasına (ticaret yaratma etkisine) yol açacaktır. Benzer şekilde, gümrük birliği öncesinde birlik dışından daha ucuza elde edilen mal, birlik içinde gümrük vergilerinin kaldırılması ve birlik dıșındaki ülkelere karşı ortak gümrük tarifesinin uygulanması sonucu, birlik içinden daha ucuza temin edilir. 
Bu da birlik dışında kalan ülkelerle ticaretin azalmasına (ticaret saptırma etkisine) neden olur (Atmaca, 1995: 21).

Gümrük birliğinin üretim etkisi analiz edilirken, en önemli hususlardan birisi birliğin oluşumunun dünya refahına net etkisinin ortaya konmasıdır. Net etki, birliğin meydana getirdiği ticaret yaratma etkisi ile ticaret saptırma etkilerinin göreceli büyüklügüne bağlıdır. Ĕger ticaret yaratma etkisi, ticaret saptırma etkisinden daha büyükse birlik ortalama kaynak verimliliğini arttıracak ve dünya refahını yükseltecektir. Tersi durumda, ticaret saptırma etkisinin ticaret yaratma etkisinden büyük olması halinde ise, dünya kaynaklarının ortalama verimliliği düşecek ve dünya refahı azalacaktır (Seyidoğlu, 1999: 208).

Gümrük birliklerinin ticaret yaratma etkileri ile ticaret saptırma etkilerini bazı basitleștirici varsayımlar altında incelemek gerekmektedir. Bu varsayımları aşağıdaki gibi sıralayabiliriz (Dura ve Atik, 2007: 13; Kılıç, 2005:23):

1- Mal ve faktör piyasalarında tam rekabet koşulları geçerlidir.

2- Gümrük vergileri spesifik değil, "advalorem” olarak uygulanmaktadır.

3- Üretim sabit maliyetlerle yapılmaktadır.

4- Ulaştırma masrafları sıfır olarak kabul edilmektedir.

5- Tek malın bulunduğu bir piyasa vardır.

6- Piyasalardaki tüm faktörler tam istihdam edilmektedir.

7- Maliyetler fiyatları belirlemektedir.

8- Üretim faktörleri ülke içinde tam hareketli, ülkeler arasında hareketsizdir.

Ayrıca yukarıda belirtilenlere ilave olarak yapılan analizlerde üç ülke yer almaktadır. Bunlardan birincisi, ev sahibi ülkedir. İkinci ülke birliğin diğer üyesidir. Üçüncü ülke ise, birlik üyesi olmayan ülkedir. Bu üçüncü ülkeler, literatürde genellikle "dış dünya" veya "üçüncü ülkeler" olarak adlandırılmaktadır.

Gümrük birliğinin üretim etkileri, ortak gümrük tarifesinin neden olduğu ticaret yaratma ve ticaret saptırma etkilerine bağlı olarak ortaya çıkacaktır. Ortak gümrük tarifesinden kaynaklanan ticaret yaratma etkisi ile yüksek maliyetle elde edilen yerli üretim daha düşük maliyetli birlik üyesi ülkenin üretimi ile ikame edilir. Böylece, üretici rantı azaltılarak, tüketici refahında artış sağlanır. Bu nedenle ticaret yaratma etkisi refah artırıcıdır. Tersine, ortak gümrük tarifesi nedeniyle yüksek maliyetli birlik üyesi ülke, birlik dışındaki daha etkin üreticilere tercih edilebilir, bu durumda oluşan ticaret saptırma etkisi tüketicinin potansiyel refahını azaltır. Bu nedenle ticaret saptırma etkisi refah azaltıcıdır (Halıcıoğlu, 1997: 62).

Ticaret yaratma etkisinin refah kazanımları iki kısımdan oluşur. Birincisi, yüksek maliyetli ülkede yerli üretimin azalması nedeniyle meydana gelen üretim kazançları, ikincisi ise düşük fiyatlardan dolayı tüketici rantında artışı ifade eden tüketim kazançlarıdır. Ticaret saptırma etkisi, en verimli ve en az maliyetle üretim yapan üreticinin birlik dışında kalması ve ürettiği malların ortak gümrük tarifesine tabi olması nedeniyle, birliğe üye olan ülkelerin bu ülkeden yaptığı ithalatın azalmasından veya durmasından kaynaklanır. Bu nedenle eğer birlik oluşturulduktan sonra, bu ülkenin birlik içinde yer alması ya da fiyat farkının 
kapanmaması nedeniyle bu ülkeden ithalatın devam etmesi bir ticaret saptırma etkisi meydana getirmez dolayısıyla bir refah azalması da söz konusu olmazdı (Seyidoğlu, 1999: 208).

Sonuç olarak ticaret yaratma etkisi ile ticaret saptırma etkisi birlikte analiz edildiğinde, ticaret yaratma etkisiyle ticaret saptırma etkisi arasındaki fark, üretim etkisinden kaynaklanan net refah etkisini ifade eder. Bu etki pozitif kaldığı sürece gümrük birliği toplumsal refahı artırır. Ortak gümrük tarifesinin büyüklüğü, gümrük birliğinin ticareti caydırıcı veya artırıcı nitelikte olup olmadığını belirler. Eğer ortak gümrük tarifesi, gümrük birliği öncesi tarifelerden daha düşük oranda belirlenirse, bu durumda birlik dışı ülkeler lehine dışsal ticaret yaratma etkisi ve dışsal ticaret saptırma etkisi oluşur. Dişsal ticaret yaratma etkileri ile dişsal ticaret saptırma etkilerinin net etkisi pozitif kaldığı sürece gümrük birliği toplumsal refah artışının elde edildiği bir ekonomik entegrasyon şekli olacaktır (Halıcıoğlu, 1997: 62).

Gümrük birliğinin oluşturulmasıyla birlikte gümrük tarifelerinin kaldırılması sonucu, göreceli olarak daha ucuza ithal edilen malların daha fazla talep edilmesi söz konusu olacaktır. Eğer fiyatı düșen maldaki talep esnekliği sıfırdan büyükse (e $>0$ ), fiyatı ucuzlayan mala yönelik talepte bir artış olacak ve dolayısıyla tüketim etkisi ortaya çıkacaktır (Dura ve Atik, 2007: 19-20). Birliğe üye olan ülkelerin ekonomik yapılarında bir uyumluluk varsa, birliğin tüm üye ülkelerin lehine olacağı ve üye ülke vatandaşlarının gelirlerinin ve refah seviyelerinin yükseleceği, tüketicilerin gelirlerinde meydana gelen artışların talebi artıracağı ve tüketime daha fazla finansal kaynak aktarılacağı kabul edilmektedir. Böylece hem birlik içinde malların ucuzlaması hem de üye ülke vatandaşlarının üretim etkisi nedeniyle gelirlerinin artması tüketim etkisi olarak değerlendirilebilir (Doğan, 2004: 5).

Birlik içinde üretim yapısının sabit kaldığı varsayımı altında iç piyasada fiyatların düşmesi, bir çeşit tüketici rantı oluşturacaktır. Diğer taraftan gümrük tarifesinin kaldırılmasıyla fiyatı düșen ithal malları, fiyatı daha yüksek benzer nitelikteki yerli malların yerine ikame edilecektir (Çak ve Çak, 2007: 14).

Viner, teorisini daha çok üretim etkisi üzerine inşa ettiğinden, çalışmalarında gümrük birliklerinin tüketim etkisi üzerinde pek durmamıştır. Ancak Meade, Gehrels ve Lipsey gibi iktisatçllar, ekonomik entegrasyonların üretim faktörlerinin en verimli şekilde kullanılmasını engelleyen tarifelerin ortadan kaldırılmasıyla, ülkeler arasındaki göreceli fiyatların değișeceğini ve buna bağlı olarak da tüketici tercihlerinde kaymalar olabileceğini ileri sürmüşlerdir. Bu şekilde tüketimde meydana gelen değişmeler, üretim etkilerindeki gibi toplumun refah düzeyini arttırıp azaltabilecektir (Karluk, 1998a: 219). Böylece tüketim etkilerini de analize dâhil eden bu iktisatçllar, gümrük birliği kurulduktan sonra malların gümrük birliği öncesi ile aynı miktarda tüketildiğini öne süren (dolayısıyla talep elastikiyetini sıfır, arz elastikiyetini sonsuz kabul eden) Viner'in bu varsayımını benimsememişlerdir (Dura ve Atik, 2007: 20).

Gümrük birliği sonucunda gümrük tarifelerinin kaldırılması yurt içinde fiyatların düşmesine neden olurken, bir mala gümrük vergisi uygulanması ise bu malın piyasa fiyatının gümrük vergisi miktarı kadar artmasına neden olur. Birlik nedeniyle kaldırılan tarifeler birlik içindeki hareketliliği arttırarak, ekonomideki tüketim yapısını da değiştirir (Karluk, 1998a: 219). Burada ticarete konu olan mal eğer ikame malı niteliğinde ise, birlik içinde pahalıya 
üretilen mal yerine daha ucuz maliyetle üretilen mal tercih edileceğinden üretim etkinliği ile birlikte olumlu tüketim etkisi de sağlanmış olacaktır (Çak ve Çak, 2007: 14-15).

Birliğe üye ülkeler arasındaki mal hareketliliği, ekonomideki göreceli fiyatları etkiler. Bunun sonucunda tüketicinin ihtiyacını daha az etkinlikte karşılayan belirli yerli mallardan, aynı ihtiyacı daha etkinlikte karşılayan mallara doğru bir kayma söz konusu olur. Göreceli olarak fiyatları değișen yerli mallar, ikame malı ise ve talep esneklikleri de sıfırdan büyükse, bu malların tüketimi değișir. Bu durumda, tarifelerin kaldırılması nedeniyle göreceli olarak ucuza ithal edilen birlik üyesi ülke malları daha çok talep edilir ve böylece gümrük birliklerinin tüketim etkileri de ortaya çıkar (Karluk, 1998a: 219).

Gümrük birliklerinin tüketime olan etkileri, olumlu ve olumsuz tüketim etkisi olmak üzere genel olarak ikiye ayrılmaktadır. Gümrük birliğinin olumlu tüketim etkisi, ticaret yaratma etkisine ve büyüklügüne paralel olarak ortaya çıkmaktadır. Olumlu üretim etkisi sonucunda birliğe üye olan ülkeler daha ucuz bir kaynaktan daha çok tüketim yapma firsatı yakalayacaklar ve böylece olumlu tüketim etkisi nedeniyle refah düzeyinin artması sağlanacaktır (Dura ve Atik, 2007: 20).

Olumsuz tüketim etkisi ise, gümrük birliğinin kurulmasıyla birlikte ticaret saptırmasının meydana gelmesi durumunda ortaya çıkar. Bir ülkenin birlik kurulmadan önce ithalatını en ucuz maliyetle üretim yapan bir ülkeden yaparken, birliğin kurulmasından sonra daha yüksek bir maliyetle üretim yapan birlik üyesi bir ülkeden ithalatını yapması durumunda, ithal edilen malın fiyatı birliğin kurulmasından önceki duruma göre yükseleceğinden bu defa olumsuz tüketim etkileri ortaya çıkar (Kılıç, 2005: 29).

Gümrük birliklerinin dıș ticaret üzerindeki etkilerini, ticaret hadleri özelinde değerlendirmek konuyu daha anlaşlabilir hale getirecektir. Ticaret hadleri, kısaca ihracat fiyatlarının ithalat fiyatlarına oranı olarak tanımlanabilir. Bir ülkenin ithal ettiği malların fiyatındaki artış ya da azalış ve ihraç ettiği malların fiyatındaki azalış ya da artış ticaret hadlerinin ülke aleyhine ya da lehine geliştiğini gösterir (Yıldırım ve Dura, 2007: 145). Ticaret hadleri, birliğin kurulmasıyla birlikte ortaya çıkan işbölümünün yaratacağı refah artışından her üye ülkeye düșen payı ifade eder (Karluk, 1998a: 224).

Gümrük birlikleri, üye ülkeler arasında gümrük tarifelerinin ve kotaların kaldırılması ve birliğe üye olmayan ülkelere karşı ortak gümrük tarifesinin uygulanması sonucunda fiyatları değiştirmek suretiyle ticaret hadleri üzerinde etkili olurlar. Böylece gümrük birliğinin kurulması, hem birlik üyesi ülkeler hem de üçüncü ülkelerde ticaret hadlerindeki değişmelere endeksli olarak refah düzeyini etkiler (Dura ve Atik, 2007: 20).

Gümrük birliğinin oluşturulmasıyla birlikte bazı ürünlerde arz ve talepte önemli bir piyasa hacmine ulaşılırsa, birliğin bu ürünlerdeki pazarlık gücü artacak, bu durum dış ticaret hadlerini birlik lehine olumlu olarak etkileyecektir. Bu olumlu etkide, birliğin ürünlerine yönelmiş olan birlik dışındaki ülkelerin arz ve taleplerinin esnek olmamasının da rolü büyüktür (Çak ve Çak, 2007: 15).

Mundell tarafından ticaret hadleri etkisi, gümrük birliği teorisine teklif eğrileri analizi ile dahil edilmiştir. Mundell'in geliştirdiği model üç ülke ve üç mal içeren bir teori üzerine kurulmuştur. Mundell, iki ülke arasında kurulacak gümrük birliği durumunda birlik dışında kalan ülkeye göre birlik içindeki her iki ülkenin ticaret hadlerinin birliğin oluşturulmasından olumlu etkileneceği sonucuna varmıştır. Diğer taraftan birleșme öncesi tarife oranı daha 
düşük olan ortağın ticaret hadlerinin birlik üyeliğinden daha olumlu yönde etkileneceği sonucuna ulaşmıştır (Yıldırım ve Dura, 2007: 145-146).

Gümrük birliği üye ülkelerin verimliliğini ve refahını artıracağından üçüncü ülkelere karşı birliğin üretim maliyetlerinde azalma olurken, pazarlık ve rekabet gücünde ise artış meydana gelecektir. Böylece birleşmeden kaynaklanan üretim hacmindeki genişleme ölçek ekonomilerinin de etkisiyle dünya fiyatlarının belirlenmesinde birliğin etkinliğini artırırken, dış ticaret hadlerinin birlik dışında kalan ülkeler aleyhine dönmesi sonucunu doğuracaktır (Elmas, 1995: 12).

\section{B. Gümrük Birliğinin Dinamik Etkileri}

Dinamik etkiler, uzun dönemde gümrük birliğinin Gayri Safi Yurt İçi Hasılanın (GSYİH) büyüme hızında meydana getirdiği etkilerdir (Yıldırım ve Dura, 2007: 146). Gümrük birliğinin oluşturulmasıyla ortaya çıkan etkiler statik etkilerle sınırlı kalmayıp, üye ülkelerin iktisadi yapılarında, üretim kapasitesi ve kaynak verimliliklerinde de köklü değişikliklere yol açar. Süreç içerisinde oluşan bu etkiler, milli gelir, kalkınma hızı ve ekonomik refahı doğrudan ilgilendiren dinamik etkilerdir (Uyar, 2000: 11).

Statik analiz, iktisadi yapıda ve teknoloji düzeyinde bir değişiklik olmadan meydana gelebilecek ticaret ve refah değişimlerinin incelenmesinde faydalı olurken, "zaman" unsurunun ekonomik analize dâhil edilmesiyle iktisadi yapı, teknoloji, milli gelir, büyüme artışı ve faktör arzlarında meydana gelen değişikliklerin açıklanmasında yetersiz kalmaktadır (Çak ve Çak, 2007: 16).

Dinamik etkiler, daha çok gümrük birliğinin üretim organizasyonu, kaynak arzı, milli gelir ve teknoloji gibi alanlarında ortaya çıkar. Birlikler kurulduktan sonra yukarıda belirtilen yapısal parametrelerde meydana gelen değişimler, birlik üyesi ülkelerin, üçüncü ülkelerin ve dünya ekonomisinin refah düzeyinin artmasını sağlar (Uyar, 2000: 11).

Gümrük birliklerinin dinamik etkileri, literatürde büyüme ya da genișleyen piyasa kavramlarıyla açıklanmaya çalışılmıştır. Genişleyen piyasa iktisadi yeniliklerin oluşmasına yol açarak, ölçek ekonomileri çerçevesinde içsel ve dışsal tasarrufların oluşturulmasını sağlayacaktır. Birliğin kurulması sonucunda sağlanan piyasa genişlemesiyle, endüstri bazında ölçek ekonomilerinden faydalanılır, etkin üretim tekniklerinin kullanımı dışsal ekonomileri ortaya çıkarır. Ayrıca, birlik içinde emek ve sermaye hareketliliği artarak faktör verimliliğinin yükselmesi ile bölgesel ticaretin rekabeti artırması sonucu bölgesel tekellerin gücünün kırılabilmesi sağlanır (Çak ve Çak, 2007: 16).

Ölçek ekonomileri, bir firma veya endüstride üretim hacmini veya üretim fonksiyonunu değiştirerek, kapasiteyi büyüterek, teknolojik yenilikleri kullanarak veya dış çevrede meydana gelen maliyet azaltıcı faktörlerden faydalanılarak verimliliği arttırmayı ya da maliyetlerde bir düşüş sağlayarak elde edilen kazançları artırmayı ifade etmektedir (Karluk, 1998a: 227). Üretim kapasitesinin gümrük birliği gibi büyük bir piyasanın ihtiyaçlarını karşılayacak şekilde artırılması, ölçek ekonomilerinin ortaya çıkmasına neden olur (Seyidoğlu, 1999: 212).

Gümrük birliği sonrası birlik piyasası genişleyince, talep artışını karşılayabilmek için firmaların üretimlerini artırmaları gerekir. Bu durumda firmalar, şayet atıl kapasiteleri varsa, bunu kullanarak ortalama maliyetlerini en aza indirerek optimal ölçekte üretim 
yapabilirler. Ĕger atıl kapasiteleri yoksa kapasite artırmak için yeni yatırımlara yönelirler (Demir ve Temur, 1998: 9). Firmalar büyümenin sağladı̆̆ı avantajla, üretim faktörlerini daha az maliyetle elde edebilir, uzmanlaşma ve yeni teknolojilerin kullanılmasıyla birlikte verimliliklerini artırırlar (Gökdemir ve Karaman, 2008: 288).

Baldwin ve Venables, ölçeğe göre artan getiri ve tekelci rekabet varsayımları altında, bir grup ülke arasında gümrük birliğinin kurulmasıyla birlikte, üçüncü ülkelerdeki firmaların da ölçek ekonomisinden faydalanmak üzere birlik içinde üretim yapmak istemeleri sonucunda mal çeşitliliğinin artmasının refah artışına neden olacağını ileri sürmüşlerdir (Ay, 2005: 32).

Dışsal ekonomi, bir üreticinin başka bir üreticiye karşılıksız yaptığı fayda veya zarar olarak tanımlanabilir (Karluk, 1998a: 229). Diğer bir ifadeyle, dışsal ekonomi bir üretici veya tüketicinin diğer bir üretici veya tüketicinin yapmış olduğu üretim ya da tüketim fonksiyonu üzerindeki olumlu veya olumsuz etkiler olarak açılanabilir. İlk kez Marshall tarafından sistematize edilen dıșsal ekonomiler kavramı, endüstride yer alan firmaların üretim maliyetleri hesaplanırken, artan getirileri tanımlamak için kullanılmıştır (Çak ve Çak, 2007: 17).

Piyasa hacmindeki büyüme, işletme dışı tasarrufları artırır. Ölçek ekonomileri, teknolojik yenilikler, rekabet ve dışsal ekonomiler bir sarmal şeklinde birbirini etkileyen benzer analizlere dayanır. Bu etkilerin varlığı; teknik bilgilerin ilerlemesine, hammadde ve ara mallarının artmasına, kalitesinin yükselmesine ve fiyatların ucuzlamasına katkı sağlar (Seyidoğlu, 1999: 212). Balassa'ya göre gümrük birliği, çeşitli vasıtalarla dışsal ekonomilerin oluşmasına zemin hazırlar. Bu vasıtalardan en bilineni olarak teknolojiyi göstermiștir. Solow ve Massell'den örnekler vererek, teknolojik gelişmenin toplam üretim fonksiyonunu yukarı kaydıracağını belirterek, aynı miktar girdiyle daha fazla çıktı elde etmenin mümkün olacağını ifade etmiştir (Çak ve Çak, 2007: 17-18).

Dışsal ekonomiler, arz ve talep koşullarındaki gelişmelere bağlı olarak, firmaların veya endüstrilerin hem özel hem de genel üretim maliyetlerini azaltabilir. Dișsal ekonomiler, endüstrinin optimum ölçeğe varmasında ve ekonomik birleşme sağlayan üye ülke piyasalarında, maliyet azaltıcı etkilerinden dolayı yerli ve yabancı yatırımcıların teşvik edilmelerinde olumlu katkıda bulunurlar (Yıldırım ve Dura, 2007: 147-148).

Büyüme ve verimlilik üzerinde olumlu sonuçlar meydana getiren dışsal ekonomiler; piyasa ve sanayinin genișlemesi, işgücü piyasasına kaliteli işgücü ve vasıflı eleman sağlanması, teknolojik altyapı ve bilginin yayılması vb. tüm endüstrinin faydalanabileceği alanlarda katkı sağlar. Ayrıca, üretim sistemlerinde ileri ve geriye doğru bağlantılar nedeniyle meydana gelebilecek içsel ve dışsal ekonomiler özel olarak verimlilik artışında uzun vadeli olumlu etkide bulunurlar (Uyar, 2000: 12).

Malinvaud'a göre, gümrük birliğine bağlı olarak ortaya çıkması beklenen dışsal ekonomiler aşağıda sıralanmıştır (Dura ve Atik, 2007: 24):

1- Gümrük birliğine üye ülkeler arasında üretim faktörleri ve malların gümrük tarifesiz olarak dolaşımı, malların son kullanıcıya daha düşük fiyatlardan ulaşmasını sağlayacaktır.

2- $\quad$ Bilgi ve teknolojinin birliğe üye ülkeler arasında serbest dolaşımı, gümrük birliği içinde nispeten geri kalmış olan bölgelerin gelişmesine katkı sağlayacaktır. 
3- Gümrük birliğinin oluşmasıyla meydana gelen geniş piyasa yapısı, risk ve belirsizlikleri azaltarak yatırımları daha kârlı ve verimli hale getirecektir.

4- Piyasanın genişlemesi, endüstrinin dolayısıyla firmaların optimum düzeyde etkin üretim ölçeğine varmalarına yardımcı olacaktır.

Gümrük birliğinin oluşturulmasıyla genişleyen piyasalarda; tekel yapısının kırılması sonucu, büyük işletmelerin kurulması ve üye ülkelerin teknolojik gelişme hızlarının yükseldiği görülmektedir. Bu durum, hem yurt dışından ileri teknolojinin alınmasına hem de ișletmelerin üretim bütçelerinde Araștırma ve Geliștirme (AR-GE) çalıșmalarına daha fazla kaynak ayırmaları sonucunu doğurur (Seyidoğlu, 1999: 212). Gümrük birliğinin teknolojik gelişmeyi artırması, rekabet artışını, ölçek büyümesini, yabancı sermaye yatırımlarının artışını ve daha ucuz ve kaliteli üretim yapmayı olanaklı hale getirir (Temiz, 2009: 126). Büyük ölçekli firmalarda meydana gelen bu etkiyi Manisalı, "teknolojik harcamanın verimliliği"ne bağlamaktadır. Üretim hacmindeki artış ve rekabet firmaların AR-GE harcamalarını da artırır. Diğer yandan büyük ișletmelerin kurulması daha fazla nitelikli elemanı ve teknoloji ithalini sağlar, bu da birlik üyesi ülkelerin üretim teknolojilerini geliştirir (Çak ve Çak, 2007: 18).

Gümrük birliği teknolojik gelișmeyi genel olarak üç șekilde artırabilir. Birincisi, artan rekabetin yurt içi firmaları daha verimli çalışmaya ve AR-GE yatırımlarını artırmaya zorlayarak teknolojik gelişmeye neden olmasıdır. İkinci olarak, daha geniş bir pazarla karşılaşan yurt içi firmaların üretim ölçeklerinin büyümelerini sağlamasıdır. Üçüncüsü ise, gümrük birliği nedeniyle artan doğrudan yabancı sermaye yatırımlarıyla gelen teknolojiler, üye ülkelerdeki teknoloji seviyesinden daha yüksek olduğunda ortaya çıkar (Yıldırım ve Dura, 2007: 148).

Teknolojide yaşanan gelişmeler, üretim teknolojisini de etkilemektedir. Üretim teknolojisindeki gelişmeler bir yandan maliyetlerin düşmesine yardımcı olurken, diğer taraftan daha fazla ürün elde edilmesine yardımcı olmakta, dolayısıyla ekonomiyi olumlu yönde etkileyerek refaha da katkı sağlamaktadır. Ayrıca, teknolojik gelişme ekonomik yapıyı güçlendirmekte ve bunun sonucu olarak kalkınma ve büyüme hızlanmaktadır. Tersine bir durumun söz konusu olmasında ise, teknolojik gelişmenin gerilediği dönmelerde, azalan verimler yasası gereği dünya ekonomisi bundan etkilenerek daralmakta ve üretim faktörleri piyasasında ciddi krizler meydana gelmektedir (Uyar, 2000: 12).

Gümrük tarifelerinin kaldırılması sonucunda, birlik içinde ticaret serbestleșip piyasa genișleyince, sermaye hareketliliği hem birlik içinde daha verimli ve kârlı üye ülkelere, hem de üçüncü ülkelerden birlik içine kaymaya başlar. Bu da birlik içinde doğrudan yatırım, üretim, gelir ve refah artışını sağlar (Demir ve Temur, 1998: 11-12). Aslında sermaye hareketliliği ile yatırımlar biri birleriyle ilintili unsurlardır. Yabancı doğrudan yatırımların varlığı, genellikle sermaye hareketliliği ile açıklanır. Hatta kimi yazarlara göre, portföy yatırımı ile birlikte yabancı doğrudan yatırım, sermaye hareketinin doğal uzantısı olarak değerlendirilir (Ertürk, 2006: 120).

Gümrük birlikleri, kaynakların etkin kullanılmasına, milli gelirin, tasarrufların ve yatırımların artmasına katkı sağlar. Ayrıca, gümrük tarifelerinin yeniden yükseltilmeyeceği konusunda yatırımcılara güven sağlayıp sermaye hareketliliğini teşvik ederek yatırımların riskini azaltır, kârlılık ve verimliliği yükseltir. Diğer taraftan, piyasa hacmindeki büyüme, 
birlik içinde üretimin daha etkin yapılmasına ve bölgeye önemli miktarda yabancı sermaye yatırımının girmesine neden olur (Seyidoğlu, 1999: 213).

Gümrük birliği dolayısıyla doğrudan yabancı sermaye yatırımlarında meydana gelen artışın genelde üçüncü ülkelere uygulanan ortak gümrük tarifesi nedeniyle birlik dışındaki ülkelerden gelmesi beklenmektedir. Üçüncü ülkelerin gümrük birliğini meydana getiren ülkelere yatırım yapmalarını cazip hale getiren nedenler şöyle sıralanabilir (Yıldırım ve Dura, 2007: 147; Dura ve Atik, 2007: 25-26):

1- Gümrük birliğinin birlik içinde gümrük tarifelerinin yeniden ihdas edilmeyeceği ya da yükseltilmeyeceği hususunda dış yatırımcılara güvence vermesi,

2- Gümrük birliklerinin neden olduğu ticaret sapmasının, birlik üyesi ülkelerin üçüncü ülkelerden yaptıkları ithalatı azaltması sonucunda, birlik dışındaki yatırımcıların birlik üyesi ülkelere yatırımda bulunmalarına yol açması,

3- Birlik içindeki verimliliğin ve ekonomik istikrarın artması, gelirin, istihdamın ve sermayenin marjinal etkinliğinin yükselmesinin yabancı yatırımcıları birlik içinde üretim faktörlerini kullanma konusunda teşvik etmesi,

4- Birlik üyesi ülkeler arasındaki rekabet ve ticaret artışının üçüncü ülke yatırımcılarını özendirmesi.

Gümrük tarifeleri veya diğer bir ifadeyle gümrük duvarları, kotalar ve diğer tarife dışı engeller ile korunan, verimli olmayan monopol yapıya sahip iç piyasalar; birlik içinde tarife ve kısıtlamaların kalkması sonucunda dış piyasa rekabeti ile karşı karşıya kalırlar (Seyidoğlu, 1999: 212). Rekabetle karşllaşan işletmeler, maliyet ve verimlilikte rekabet edemedikleri piyasaları terk etmek zorunda kalırlar. Dıșarıdan gelen mallarla rekabet eden firmalar ise verimliliklerini artırarak maliyetlerini azaltırlar. Gümrük birliği sonunda meydana gelen rekabet ortamı, yatırımların ve etkinliğin artmasına yol açarken, monopol piyasaların gücünün azalmasına neden olur (Dura ve Atik, 2007: 23).

Gümrük birliği nedeniyle ticaretin serbestleştirilmesi, monopolcü rekabet ve oligopolistik piyasa şartlarında fiyat-maliyet marjlarının azalmasına, firmaların ölçeklerinin büyümesine ve rekabet yoluyla kaynak paylaşımındaki etkinliği artırarak fiyatların düşmesine neden olmaktadır (Çak ve Çak, 2007: 18). Gümrük birliğinin rekabet etkisi genel olarak iki şekilde ortaya çıkar. Birincisi, gümrük birliğinin doğrudan yabancı sermaye yatırımlarını özendirmesi sonucu rekabetin artmasıdır. İkincisi ise, birlik içinde ticaret hacminin artmasından dolayı rekabetin artmasıdır (Yıldırım ve Dura, 2007: 146).

Venables, ölçeğe göre artan getiri varsayımı altında mal üreten ve eksik rekabet piyasasına sahip olan ülkeler arasında gümrük birliği kurulmasının, birlik dışında kalan ülkelerde refahı azaltacağını, birlik üyesi ülkelerde ise refahı artıracağını öne sürer (Ay, 2005: 32). Rekabet politikasının esas amacı, üretim faktörleri arasındaki dağılımı etkin kılarak, ülke refahını en üst seviyeye çıkarmaktır (Hobikoğlu, 2007: 68-69). Rekabet nedeniyle birlik içinde verimlilik artışı, maliyet ve fiyat düşüşü gözlenirken, bazı durumlarda yoğun rekabet ortamı ulusal tekelleşmenin yerini birlik ölçeğinde daha büyük tekelleşmeye bıraktığı görülür. Birliğin kurulmasıyla meydana gelen rekabet avantajlarından en üst seviyede faydalanmak için ortak bir rekabet politikasının izlenmesi gerekmektedir (Uyar, 2000: 11). 


\section{Sonuç ve Değerlendirme}

Dünya ekonomisinde her geçen gün mal ve hizmet üretim ve ticaretinde meydana gelen genişleme, serbest ticaretin önündeki engellerin kaldırılması/azaltılması, uluslararası sermaye hareketliliğinin ivme kazanması, üretim ve pazarlama teknolojisindeki baş döndürücü değişim ve uluslararası entegrasyon hareketlerindeki artış sonucunda kurulan örgütlenme modelleri, uluslararası rekabet gücü kavramını da beraberinde getirmektedir. Ülkeler son dönemde hem gelişen uluslararası ticaretten aldıkları payı büyütmek hem de uluslararası ticaretteki rekabet güçlerini artırmak için ikili ve çoklu; bölgesel ve bölge dıșı ekonomik entegrasyon modellerini daha fazla önemsemektedirler. Bu çalışmamızda uluslararası ekonomik entegrasyon modellerinden birisi olan gümrük birliklerinin oluşum süreci ile gümrük birliği teorisi ayrıntılı olarak incelenmiștir. Ayrıca gümrük birliğinin ekonomik etkileri statik ve dinamik etkiler bağlamında irdelenmiştir.

İkinci Dünya Savaşının bitmesiyle birlikte yeni bir Dünya düzeni kurulmuştur. Kuşkusuz bu yeni düzenin en önemli unsurlarından biri de uluslararası ticaret olmuștur. 1948'den beri GATT ile uluslararası ticaretin önündeki engeller bir taraftan kaldırılmaya/azaltılmaya çalışılırken, diğer taraftan uluslararası ticaretin bölgesel entegrasyonlar yoluyla örgütlenmesine yönelik istisnai durumlar oluşturulmuştur. Ekonomik entegrasyonları en gevșek entegrasyon modelinden en sıkı entegrasyon modeline doğru beş ana bașlık altında toplamak mümkündür. Tercihli ticaret anlaşmaları ve serbest ticaret alanları diğer entegrasyon modellerine göre daha gevșek ve ülkelerin dış ticaret politikalarını daha az kısıtlamaya tabi tutarken, gümrük birlikleri ve daha ileri aşamaları ifade eden ortak pazar ve ekonomik birlikler ve siyasal bütünleșmeler modellerinde, ülkelerin diş ticaret politikalarını bir araya geldikleri birliklerin üst organlarına devrederek birbirlerine daha bağımlı bir dış ticaret politikasını tercih ettikleri görülmektedir.

Uluslararası ekonomik entegrasyon hareketleri içerisinde en dikkat çeken modellerden biri gümrük birlikleridir. 1789'da ABD eyaletleri arasında, 1834'te henüz siyasi birliğini tamamlamamış olan Alman devletleri arasında "Zolverein", 1932'de Kıta Avrupa ülkeleri arasında "Benelüx" ve nihayet 1957 Roma Anlaşmasıyla "Avrupa Ekonomik Topluluğu" adıyla gümrük birlikleri örnekleri karşımıza çıkmaktadır. Tabi ki bu gümrük birlikleri arasında ülkemizin de 1996 yılından beri içerisinde yer aldığı Gümrük Birliği en somut ve en çok bilinen örnektir.

Uluslararası ekonomik entegrasyon hareketleri içerisinde gevşek ve sıkı model tanımlamasında orta yerde duran gümrük birlikleri modeli, çalışmamızın ikinci kısmında gümrük birliği teorisi adı altında bu teorinin oluşum süreci J. Viner'in katkıları bağlamında ayrıntılı olarak irdelenmiștir. Ayrıca gümrük birliğinin ekonomik etkileri, gümrük birliğinin statik ve dinamik etkilerine yer verilmek suretiyle ticaret yaratma ve ticaret saptırma etkileri çerçevesinde analiz edilmiştir. Yine statik etkiler kapsamında üretim ve tüketim etkileri ile dış ticaret etkileri değerlendirilmiș, dinamik etkiler olarak da ölçek ekonomileri etkileri, dışsal ekonomiler etkileri, teknolojik gelişme ve ilerlemelere etkileri, sermaye hareketliliği ve yatırımları özendirme etkileri ve rekabet artırıcı etkileri etraflıca irdelenmiştir.

Bu çalışmada gümrük birliği teorisinde yer verilen statik ve dinamik etkilerin ne ölçüde gerçekleștiği, ticaret yaratıcı ve saptırıcı etkilerin hangi büyüklükte olduğu hususlarına değinilmemiş, sadece teori bağlamında bu etkilerin olacağı varsayılmıștır. Daha nicel 
çalışmalarla bu etkiler sınanmalıdır. Bu bağlamda 2020 yılı itibariyle 25'inci yılını tamamlayan Türkiye-AB Gümrük Birliği Anlaşmasına bu çalışmamızda somut olarak yer verilmemiş olmakla birlikte hem bahse konu etkiler hem de Türkiye olarak gündeme getirilen Gümrük Birliği Anlaşmasının güncellenmesi talebi kapsamında konunun araştırılmasının yararlı olacağı düşünülmektedir.

\section{Kaynaklar}

Atmaca, R. (1995). Gümrük Birliği ve olası etkileri. Ekonomik Yaklaşım, 6(16), 15-27.

Ay, S. Ç. (2005). Gümrük Birliği sürecinde Türkiye'nin dış ticaretinde meydana gelen yapısal değişmeler. İktisadi Araştırmalar Vakfı.

Aynagöz, Ö. (2002). Gümrük birliği teorisinin gelişimi. Ekonomik Yaklaşım, 13(44), 23-39.

Bakkalcı, A. C. (2002). Avrupa Birliği ile Türkiye arasında gerçekleștirilen Gümrük Birliği'nin kaynak dağılımı üzerine etkileri. Dokuz Eylül Üniversitesi İktisadi ve İdari Bilimler Fakültesi Dergisi, 17(2), 39-53.

Çak, D. ve Çak, M. (2007). Gümrük Birliği'nin getirdikleri ve götürdükleri: Dış ticaret vergileri ve ihracat gelirleri analizi. Yayın No: 2007-68. İstanbul Ticaret Odası.

Demir, O. ve Temur, Y. (1998). Gümrük Birliği'nin ilk iki yılı değerlendirmesi. Dış Ticaret Dergisi, (11).

Doğan, N. (2004). On yıllık dönemde Gümrük Birliği'nin etkileri ve sonuçları üzerine bir değerlendirme. Mevzuat Dergisi, (79), 1-12.

Doğan, A. ve Uzun, A. (2014). Serbest ticaret anlaşmalarının Türkiye'nin dış ticaretine etkileri. C.Ü. Íktisadi ve İdari Bilimler Dergisi, 15(1), 325-344.

Dura, C. ve Atik, H. (2007). Avrupa Birliği Gümrük Birliği ve Türkiye (Genişletilmiş 3. Baskı). Nobel Yayın Dağıtım.

Elmas, G. (1995). Gümrük Birliği ile Türkiye. Ekonomik Yaklaşım, 6(16), 5-13.

Erçakar, M. E. (2005). Gümrük Birliği ve Türkiye'nin dış ticaretine etkileri. İş,Güç, Endüstri Illişkileri ve İnsan Kaynakları Dergisi, 7(2), 59-194.

Ertürk, E. (2006). Uluslararası İktisadi Birleșmeler (Geliştirilmiş 4. Baskı). Alfa Aktüel Yayınları.

Gökdemir, L. ve Karaman, E. (2008). Onuncu yılında Gümrük Birliği: Ne beklendi? Ne gerçeklești? Fırat Üniversitesi Sosyal Bilimler Dergisi, 18(2), 277-296.

Gürlesel, C. F. ve Alkin, K. (2010). Avrupa Birliği'nin serbest ticaret anlașmalarına Türkiye'nin de dahil edilmesi. İstanbul Ticaret Odası Yayınları.

Halıcıoğlu, F. (1997). Türkiye AB Gümrük Birliği ve alternatiflerinin statik etkileri. Sosyal Bilimler Dergisi, 3(1), 61-72.

Hobikoğlu, E. H. (2007). Gümrük birliklerinin ekonomik etkileri ve Türkiye ekonomisi: Gümrük Birliği yansımaları. Sosyal Bilimler Dergisi, 65-82.

Karluk, R. (1998a). Uluslararası Ekonomi (Yenilenmiş 5. Baskı). Beta Basım Yayım Dağıtım A.Ş. 
Karluk, R. (1998b). Uluslararası Ekonomik Mali ve Siyasal Kuruluşlar. (4. Baskı). Turhan Kitabevi.

Kılıç, R. (2005). Türkiye-AB ilişsileri ve Gümrük Birliği (Gözden Geçirilmiş 2. Baskı). Siyasal Kitabevi.

Kızıltan, A., Ersungur, M., ve Polat, Ö. (2008). Gümrük Birliği'nin Türkiye'nin Avrupa Birliği ile ihracat ve ithalatına etkisi. Iktisadi ve İdari Bilimler Dergisi, 22(1), 83-99.

Moussis, N. (2004). Avrupa Birliği Politikalarına Giriş Rehberi (Guide to Eurpean Policies). (Çev.: A. Fethi). Mega Press.

Seyidoğlu, H. (1999). Uluslararası Íktisat: Teori, Politika ve Uygulama. (13. Baskı). Güzem Yayınları.

Temiz, D. (2009). Gümrük Birliği ile birlikte Türkiye'nin dıș ticaretinde yapısal değişimler oldu mu? Ankara Avrupa Çalışmaları Dergisi, 8(1), 115-138.

Uyar, S. (2000). Ekonomik bütünleşmeler ve gümrük birliği teorisi. Dış Ticaret Dergisi, 19(4).

Yıldırım, E. ve Dura, C. (2007). Gümrük Birliği'nin Türkiye ekonomisi üzerindeki etkileri konusundaki literatüre bir bakıș. Erciyes Üniversitesi İktisadi ve İdari Bilimler Fakültesi Dergisi, (28), 141-177.

Yıldız, M. (1999). Ekonomik Entegrasyonlar ve AB. Dış Ticaret Dergisi, (15), 1-14 